The International Journal of Indian Psychology

ISSN 2348-5396 (e) | ISSN: 2349-3429 (p)

Volume 4, Issue 1, No. 77, DIP: 18.01.064/20160401

ISBN: 978-1-365-51571-2

http://www.ijip.in | October-December, 2016

\title{
Biopsychosocial Distress among Offspring of Mentally Ill Clients
}

\author{
Joshy M George $^{1 *}$, Reena George ${ }^{2}$
}

\section{ABSTRACT}

Mental illness causes social isolation of mentally ill clients and their children. The offspring of mentally ill clients experience psychosocial distress due to rejection and discrimination from the public, they experience low self-esteem due to inadequate meeting of their needs by their parental figures when comparing with their contemporary children. Offspring of mentally ill clients experience stress and inadequate coping with their parental mental illness. Families experience social isolation, financial hardship and marital discord. The children in the family were genetically, psychologically and environmentally distressed (Reupert A, Mayberry D, 2010). Children of mentally ill parents face many problems like neglect, exposure to violence and trauma, housing and custodial instability, developmental delays, stigma and isolation (Hoppingwinn A,2012).Ineffective coping of children leads to poor psychosocial development, compromised emotional and mental wellbeing (Aldridge J,2012). It is important to identify the Bio psychosocial distress among offspring of mentally ill clients. The main objectives of the study were to assess the Bio psychosocial distress among offspring of mentally ill clients, find the relationship among Biological, Psychological and Social distress in offspring of mentally ill clients and determine the association between bio psychosocial distress and selected demographic variables of offspring of mentally ill clients.

Keywords: Biopsychosocial Distress, Offspring of Mentally Ill Clients

\section{Operational definition}

Bio psychosocial distress: Bio psychosocial distress refers to the physical, mental and social tension and strain experienced by the offspring of mentally ill clients in terms of the scores obtained in response to the Modified Kessler's rating scale.

Offspring of mentally ill clients : Offspring of mentally ill clients refers to the individuals in the age group of 20 to 50 years who take care of their mentally ill parents (mother, father or both) who are on follow up or admitted in a mental health care setting.

\footnotetext{
${ }^{1}$ Staff Nurse, IQRAA Mental Health care Centre, Calicut, India

${ }^{2}$ Associate Professor \& Head, Dept. of Mental Health (Psychiatric) Nursing, MIMS College of Nursing,

Malappuram, India

*Responding Author

(C) 2016 J George, R George; licensee IJIP. This is an Open Access Research distributed under the terms of the Creative Commons Attribution License (http://creativecommons.org/licenses/by/2.0), which permits unrestricted use, distribution, and reproduction in any Medium, provided the original work is properly cited.
} 


\section{Biopsychosocial Distress among Offspring of Mentally III Clients}

\section{MATERIALS AND METHOD}

A quantitative approach with non-experimental descriptive survey design was adopted to carry out the study. The major variable of the study was Biopsychosocial distress and the study conducted in a selected Psychiatric Rehabilitation Centre, Calicut. The Sample consisted of 100 offspring of mentally ill clients in the age group of 20 to 50 years, who take care of their mentally ill parents (mother, father or both) who are on follow up or admitted in a mental health care setting selected through convenience sampling technique. The study included only the offspring who are taking care of their mentally ill parents and related to the parents through blood or adoption. The data collection instruments were a Socio demographic Proforma and a bio psychosocial distress scale. It is a modified version of Kessler's psychological distress scale. The researcher included items assessing Biological and Social distress for assessing Biopsychosocial distress. The reliability coefficient of internal consistency was computed using test retest method and "Cronbach's Alpha” and it was 0.8. Ethical clearance was obtained from IRB of selected Psychiatric Rehabilitation centre and an Informed consent was obtained from offspring of mentally ill clients. Confidentiality of the information collected was ensured. Data collection period was 6 weeks. The collected data were analysed using SPSS17.






\section{Conceptual Framework of the study}

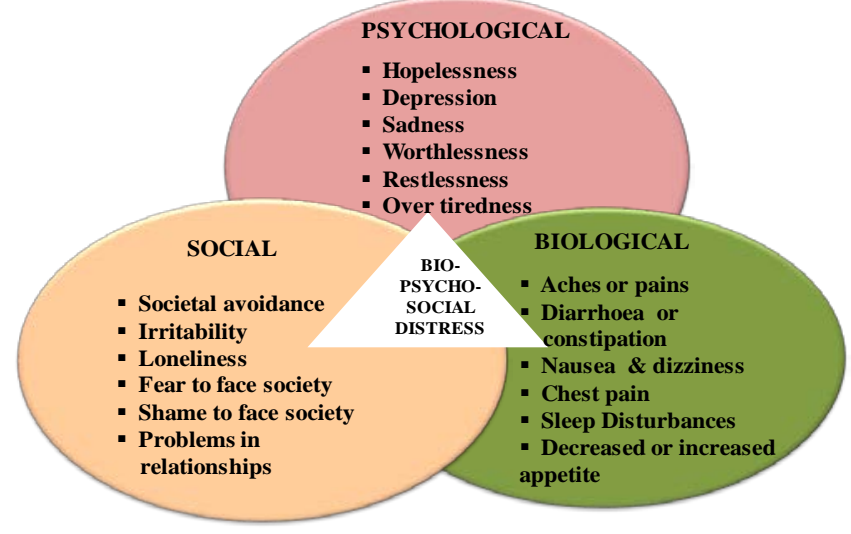

CONCEPTUAL FRAME WORK OF BIOPSYCHOSOCIAL DISTRESS AMONG OFFSPRING OF MENTALLY ILL CLIENTS BASED ON GEORGE ENGEL'S BIOPSYCHOSOCIAL MODEL

\section{RESULTS}

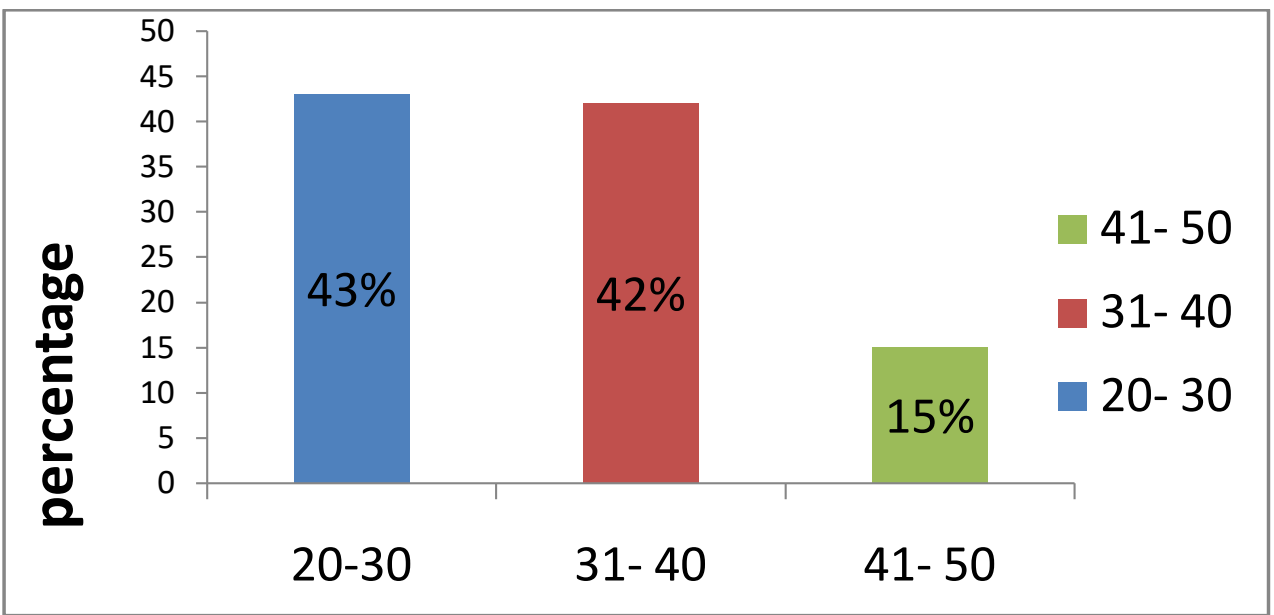

\section{Figure 1: Distribution of sample based on age}

The data depicted in figure 1 show that the majority of the sample belong to the age group of 2030 years. 


\section{Biopsychosocial Distress among Offspring of Mentally III Clients}

\begin{tabular}{lcc}
$\begin{array}{l}\text { Socio demographic } \\
\text { variables }\end{array}$ & Frequency & Percentage (\%) \\
\hline & & \\
Marital status & 30 & 30 \\
Un married & 43 & 43 \\
Married & 13 & 13 \\
Divorced & 10 & 10 \\
Widowed & 4 & 4 \\
Separated & & \\
Type of family & 48 & 48 \\
Nuclear family & 52 & 52 \\
Joint family & 5 & \\
\hline
\end{tabular}

\section{Table 1-Distribution of sample based on marital status and type of family}

The data in Table 1 reveal that most of the sample (43\%) was married and $48 \%$ were living in nuclear family.

\begin{tabular}{lcc}
\hline $\begin{array}{l}\text { Socio demographic } \\
\text { variables }\end{array}$ & Frequency & Percentage (\%) \\
\hline & & \\
Family income & 16 & 16 \\
Below 5000 & 52 & 52 \\
5001 - 10000 & 30 & 30 \\
10001 - 20000 & 4 & 4 \\
Above 20000 & & \\
Religion & 28 & 28 \\
Hindu & 34 & 34 \\
Christian & 38 & 38 \\
Muslim & & \\
\hline
\end{tabular}

Table 2-Distribution of sample based on family income and religion

Table 2 shows that most of the sample ( $52 \%$ ) had a monthly family income of Rs. 500110000 and the $28 \%$ were Hindus. 
Biopsychosocial Distress among Offspring of Mentally III Clients

\begin{tabular}{lcc}
$\begin{array}{l}\text { Socio demographic } \\
\text { variables }\end{array}$ & Frequency & Percentag \\
\hline & & \\
Education & 32 & 32 \\
Basic education & 30 & 30 \\
High school & 22 & 22 \\
Higher secondary & 16 & 16 \\
Degree and above & & \\
Occupation & 30 & 30 \\
Un employed & 19 & 19 \\
Daily wages & 29 & 29 \\
Private job & 6 & 6 \\
Government job & 16 & 16 \\
Self employed & &
\end{tabular}

\section{Table 3-distribution of sample based on education and occupation}

The data portrayed in Table 3 show that 32\% of the sample had only basic education and 30\% were unemployed.



Figure 2: Distribution of sample based on family history of mental illness

The data represented in the Figure 2 reveal that most of the sample (44\%) had family history of mental illness in maternal family and $28 \%$ each had mental illness in fathers family and both the families. 


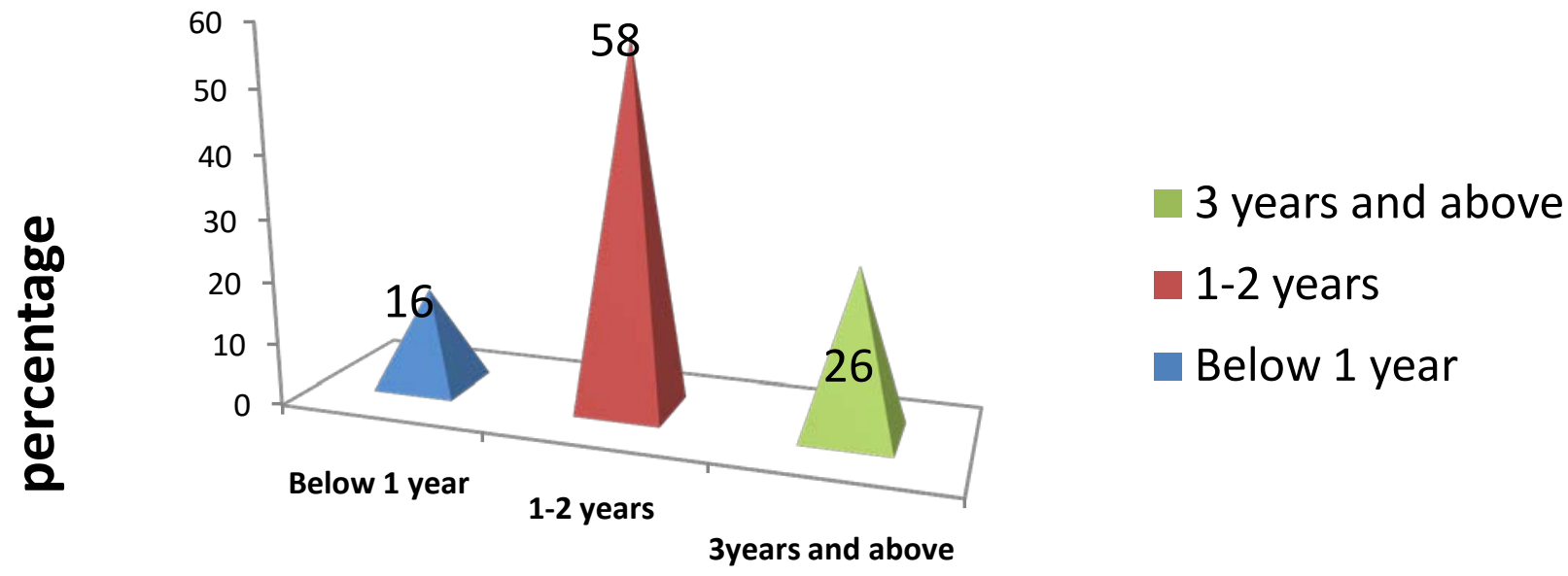

Figure 3: Distribution of sample based on duration of mental illness in their parents

The data in Figure 3 show that majority of the offspring( 58\%) had mental illness in their parents from 1-2 years and 26\% had 3years and above.

\begin{tabular}{|c|c|c|}
\hline $\begin{array}{l}\text { Socio demographic } \\
\text { variable }\end{array}$ & Frequency & Percentage (\%) \\
\hline
\end{tabular}

Mentally ill person

$\begin{array}{lcc}\text { Father } & 27 & 27 \\ \text { Mother } & 58 & 58 \\ \begin{array}{l}\text { Father and mother } \\ \text { Dependent family }\end{array} & 15 & 15 \\ \text { members } & & \\ \text { No one } & & \\ 1-2 & 11 & 11 \\ 3-5 & 53 & 53 \\ 5 \text { and above } & 29 & 79\end{array}$

Table4-distribution of sample based on mentally ill person in the family and dependent family members

The table 4 reveal that 58\% of the offspring had mothers as mentally ill and $27 \%$ had fathers as mentally ill whereas $15 \%$ both the parents as mentally ill. 
Biopsychosocial Distress among Offspring of Mentally III Clients

\begin{tabular}{|l|c|c|c|c}
\hline Variable & Category & Range of scores & Frequency (f) & $\begin{array}{c}\text { Percentage } \\
\text { (\%) }\end{array}$ \\
\hline \multirow{3}{*}{$\begin{array}{l}\text { Biopsychosocial } \\
\text { distress }\end{array}$} & $\begin{array}{c}\text { No distress } \\
\text { distress }\end{array}$ & $30-60$ & 31 & 31 \\
\cline { 2 - 5 } & $\begin{array}{c}\text { Moderate } \\
\text { distress }\end{array}$ & $75-90$ & 16 & 48 \\
\cline { 2 - 5 } & $\begin{array}{c}\text { Severe } \\
\text { distress }\end{array}$ & $90-150$ & 5 & 16 \\
\hline
\end{tabular}

Table 5 : Frequency and percentage of sample based on Bio psychosocial distress

Table 5 disclose that $48 \%$ of the sample had mild bio psychosocial distress whereas $5 \%$ had severe bio psychosocial distress.

\begin{tabular}{|l|c|c|c|c}
\hline Variable & Category & Range of scores & Frequency (f) & $\begin{array}{c}\text { Percentage } \\
\text { (\%) }\end{array}$ \\
\hline \multirow{3}{*}{ Biological distress } & No distress & $10-19$ & 28 & 28 \\
\cline { 2 - 5 } & $\begin{array}{c}\text { Mild } \\
\text { distress }\end{array}$ & $20-24$ & 44 & 44 \\
\cline { 2 - 5 } & $\begin{array}{c}\text { Moderate } \\
\text { distress }\end{array}$ & $25-29$ & 18 & 18 \\
\cline { 2 - 5 } & $\begin{array}{c}\text { Severe } \\
\text { distress }\end{array}$ & $30-50$ & 10 & 10 \\
\hline
\end{tabular}

\section{Table 6 : Frequency and percentage of sample based on Biological distress}

Table 6 portray that $10 \%$ of the sample had severe biological distress, $18 \%$ had moderate distress and $44 \%$ mild biological distress.

\begin{tabular}{|l|l|}
\hline Major areas of Biological distress & Percentage (\%) \\
\hline Aches or pain for no good reasons & 89 \\
\hline Diarrhoea or constipation & 87 \\
\hline Frequent colds & 92 \\
\hline Increased or decreased appetite & 91 \\
\hline Sleep disturbances & 85 \\
\hline
\end{tabular}

Table 7- percentage of the sample based on Major Concerns In Biological Distress

(C) The International Journal of Indian Psychology, ISSN 2348-5396 (e)| ISSN: 2349-3429 (p) | 34 
Biopsychosocial Distress among Offspring of Mentally III Clients

\begin{tabular}{|l|c|c|c|c}
\hline Variable & Category & Range of scores & Frequency (f) & $\begin{array}{c}\text { Percentage } \\
\text { (\%) }\end{array}$ \\
\hline \multirow{4}{*}{$\begin{array}{l}\text { Psychological } \\
\text { distress }\end{array}$} & $\begin{array}{c}\text { No distress } \\
\text { distress }\end{array}$ & $10-19$ & 33 & 33 \\
\cline { 2 - 5 } & $\begin{array}{c}\text { Moderate } \\
\text { distress }\end{array}$ & $25-29$ & 33 & 33 \\
\cline { 2 - 5 } & $\begin{array}{c}\text { Severe } \\
\text { distress }\end{array}$ & $30-50$ & 27 & 27 \\
\hline
\end{tabular}

Table 8 : Frequency and percentage of sample on the basis of Psychological distress

\section{Major areas of Psychological distress Percentage (\%)}

Tired out for no good reason

85

Feel that nothing could calm you down

Hopeless

94

Restless

93

Worthless

79

Table 9 -percentage of sample based on major concerns in psychological distress

\begin{tabular}{|l|c|c|c|c}
\hline Variable & Category & Range of scores & Frequency (f) & $\begin{array}{c}\text { Percentage } \\
\text { (\%) }\end{array}$ \\
\hline \multirow{3}{*}{ Social distress } & No distress & $10-19$ & 35 & 35 \\
\cline { 2 - 5 } & $\begin{array}{c}\text { Mild } \\
\text { distress }\end{array}$ & $20-24$ & 37 & 37 \\
\cline { 2 - 5 } & $\begin{array}{c}\text { Moderate } \\
\text { distress }\end{array}$ & $25-29$ & 21 & 21 \\
\cline { 2 - 5 } & $\begin{array}{c}\text { Severe } \\
\text { distress }\end{array}$ & $30-50$ & 7 & 7 \\
\hline
\end{tabular}

Table 10 : Frequency and percentage of sample with regard to the Social distress 
Biopsychosocial Distress among Offspring of Mentally III Clients

\begin{tabular}{|l|l|}
\hline Major areas of Social distress & Percentage (\%) \\
\hline Personal isolation & 93 \\
\hline Feel society is avoiding & 88 \\
\hline Feel that not be able to do job & 83 \\
\hline Unable to maintain smooth relationship & 82 \\
\hline Fear to face society & 82 \\
\hline
\end{tabular}

Table 11- major concerns in social distress

\begin{tabular}{|l|l|l|}
\hline Domains of distress & Pearson correlation ( r) & P value \\
\hline Biological and Psychological distress & 0.664 & 0.001 \\
\hline Psychological and Social distress & 0.712 & 0.001 \\
\hline Social and Biological distress & 0.592 & 0.001 \\
\hline
\end{tabular}

Table 12: Relationship among Biological, Psychological and Social distress

\begin{tabular}{|l|c|c|c}
\hline Variable & $\begin{array}{c}\text { Chi square } \\
\text { value }\end{array}$ & df & p value \\
\hline Age & 16.716 & 6 & $\mathbf{0 . 0 1 0}^{*}$ \\
\hline Gender & 6.314 & 3 & 0.097 \\
\hline Marital status & 10.564 & 12 & 0.567 \\
\hline Type of family & 6.287 & 3 & 0.098 \\
\hline Family income & 6.848 & 9 & 0.653 \\
\hline Religion & 7.253 & 9 & 0.611 \\
\hline Education & 21.702 & 9 & $\mathbf{0 . 0 1 0 *}$ \\
\hline
\end{tabular}

Table 13: Association between Biopsychosocial distress and selected demographic variables

\begin{tabular}{|l|c|c|c}
\hline Variable & $\begin{array}{c}\text { Chi square } \\
\text { value }\end{array}$ & df & pvalue \\
\hline Occupation & 16.677 & 12 & 0.162 \\
\hline History of mental illness & 1.054 & 6 & 0.983 \\
\hline Mentally ill person in the family & 2.263 & 6 & 0.894 \\
\hline Duration of mental illness & 8.344 & 6 & 0.214 \\
\hline $\begin{array}{l}\text { Presence of health care } \\
\text { professional in the family }\end{array}$ & 14.625 & 3 & 0.072 \\
\hline $\begin{array}{l}\text { Dependent family members } \\
\text { Present disease history of } \\
\text { offspring }\end{array}$ & 8.248 & 9 & 0.509 \\
\hline
\end{tabular}

Table 14: Association between Biopsychosocial distress and selected demographic variables

(C) The International Journal of Indian Psychology, ISSN 2348-5396 (e)| ISSN: 2349-3429 (p) | 36 


\section{Biopsychosocial Distress among Offspring of Mentally III Clients}

\section{CONCLUSION}

The result of the study reveals that among 100 offspring of mentally ill clients, $69 \%$ had Biopsychosocial distress. Among them $48 \%$ had mild, 16\% had moderate and 5\% had severe Biopsychosocial distress, which has to be address critically to prevent incidence of mental illness among offspring of mentally ill. There was a significant relationship among Biological, Psychological and Social distress. There was a significant association between Biopsychosocial distress and selected demographic variables such as age and education.

\section{Acknowledgments}

The author appreciates all those who participated in the study and helped to facilitate the research process.

\section{Conflict of Interests}

The author declared no conflict of interests.

\section{REFERENCE}

American Academy of Child and Adolescent Psychiatry Children of parents with mental illness [document on internet] America.[updated2008December]. Available from http://www.aacap.org/cs/root/factsforfamilies/children

Mental health statistics in India-action for mental illness [document on internet].Available from http://www.acmiindia.com/ac/mental-health-statistics-in-india.

The minds foundation, alleviating suffering from mental illness through a grassroots approach [document on internet]http://www.mindsfoundation.org.

How to cite this article: J George, R George (2016), Biopsychosocial Distress among Offspring of Mentally Ill Clients, International Journal of Indian Psychology, Volume 3, Issue 4, No. 77, ISSN:2348-5396 (e), ISSN:2349-3429 (p), DIP:18.01.064/20160304, ISBN: 978-1-365-51571-2 